\title{
Opettajaopiskelijoiden käsityksiä oppimisesta erilaisissa oppimisympäristöissä
}

\author{
Koulutuspoliittisessa keskustelussa korostuu \\ oppimisympäristöosaaminen, joka kuuluu opettajan \\ työelämätaitoihin. Opettajankoulutuksessa tulisi käsitellä niin \\ koulutusjärjestelmän ulkopuolelle ulottuvien oppimisympäristöjen \\ merkitystä oppimisprosessien jatkumoissa kuin koulun \\ ulkopuolisiin toimijoihin ulottuvia verkostoitumistaitoja. Vain \\ osa opettajaksi opiskelevista omaksuu käsityksen oppimisesta \\ elämänmittaisena, kaikkialla mahdollistuvana prosessina.
}

$\boldsymbol{y}$

VUOROVAIKUTTEISIA OPPIMISYMPÄRISTÖJÄ ja niiden merkitystä opetusta rikastavina ja syventävinä resursseina on korostettu 2010-luvun oppimiskeskustelussa. Koulutusta ohjataan normeilla yhä vahvempaan yhteistyöhön muiden toimijoiden, kuten järjestöjen, yritysten ja museoiden, kanssa, mikä näkyy esimerkiksi opetussuunnitelmien perusteissa (Opetushallitus 2014), opetuksen lainsäädännössä (Laki ammatillisesta koulutuksesta 531/2017; Ammattikorkeakoululaki 932/2014) ja opettajankoulutuksen kehittämislinjauksissa (Opetus- ja kulttuuriministeriö 2016).

Koulutusorganisaation ja sen fyysisen ympäristön suhde on osoittautunut monimuotoiseksi.
Formaalia eli muodollista koulutusta edustava oppilaitos voi tuottaa oppimisympäristönä alueelliseen yhteisöönsä informaalia eli muodollisen koulutuksen ulkopuolelle sijoittuvaa oppimista (Rajaniemi, Häkli, Rauhala \& Sumkin 2018), ja oppilaitosta ympäröivän informaalin oppimisympäristön käyttö formaalissa koulutuksessa voi syventää oppimista (Chang, Hagman, Chien \& Cho 2012).

Oppimisympäristön käsitteellä on myös sosiaalinen ulottuvuus. Opettajaopiskelijoiden näkökulmasta kiinteä osallistuminen kenttäkoulujen alueellisiin yhteistyöverkostoihin tukee heidän valmiuttaan reagoida koulujen lähialueiden muutostarpeisiin. Oppimisen näkökulmasta koulun lähialueet tulisikin 


\section{OPETTAJANKOULUTUKSESSA \\ TULEE KOROSTAA}

TULEVAISUUDEN VAATIMAA

\author{
OSAAMISTA, KUTEN \\ ONGELMANRATKAISUN JA
}

KRIITTISEN AJATTELUN

TAITOJA.

ymmärtää lasten kasvuun liittyvänä sosiaalisena oppimisympäristönä (Payne \& Zeichner 2017).

Viimeistään tulevaisuuden taitoihin suuntautuvan (21st Century Skills) ajattelun (esim. Ananiadou \& Claro 2009; Saltmarsh, Chapman, Campbell \& Drew 2015) myötä esimerkiksi digitalisaation ja moniulotteisen yhteistyön taidot ovat nousseet tulevaisuussuuntautuneeseen oppimisympäristö- ja oppimiskeskusteluun. Digitalisaatio vaikuttaa tiedon ja oppimisen avoimuuteen ja laajemmin ajateltuna digitaalisen yhteiskunnan kansalaisuuteen.

Perinteisen formaalin koulutuksen ja monimuotoistuneen informaalin oppimisen keskinäinen suhde vaatii esimerkiksi koulutusjärjestelmän käyttöön valittavien sähköisten oppimisympäristöjen kriittistä tarkastelua. Teknologioiden valinta edellyttää niiden taustojen tuntemista. Oppimisympäristöjen tuottajien intresseihin voi liittyä poliittis-taloudellisia linjauksia (Mertala 2019), tai ympäristöt voivat kerätä tietoa käyttäjistään (Parviainen 2015). Siksi opettajankoulutuksessa tulee korostaa tulevaisuuden osaamistarpeiden, esimerkiksi ongelmanratkaisun ja kriittisen ajattelun (Holma 2013) sekä medialukutaitojen (List, Brante \& Klee 2020), osaamista.

Opettajaksi opiskelevien oppimisympäristöajattelun kehittyminen on tärkeä työelämätaito. Lisäksi se on osa opettajankoulutuksen oppimisprosessia. Opettajien ammatillinen kehittyminen nähdään jatkuvana ja kompleksisena oppimisprosessina, jossa henkilökohtaiset kokemukset ja ammatillinen tieto vaikuttavat toisiinsa (Webster-Wright 2009; Leeferink, Koopman, Beijaard \& Schellings
2019). Ammatillisen osaamisen ylläpitäminen edellyttää opettajalta kykyä jatkuvaan omaehtoiseen ja informaaliin työssäoppimiseen sekä reflektointiin (Grosemans, Boon, Verclairen, Dochy \& Kyndt 2015; Legat, Raemdonck, Beausaert \& März 2019). Opettajaopiskelijoille tulee jo koulutuksessa tuottaa reflektiivisen ajattelun valmiuksia, jotta he voivat sitoutua kehittämään itseään työuransa aikana (Yeung, Craven \& Kaur 2014).

Opettajankoulutuksessa tulee tunnistaa yliopistollisten opintojen, työelämässä oppimisen ja nopean yhteiskunnallisen muutoksen merkityksiä opettajan profession rakentumisessa (Wilson \& Demetriou 2007; Jones \& Dexter 2014). Kun koulutusjärjestelmää kehitetään määrätietoisesti, erityisesti opettajaopiskelijoilta vaaditaan valmiutta oppimisen ja oppimisympäristöjen kriittiseen tarkasteluun ja pedagogiseen kehittämiseen. Siksi tutkimusongelmamme ovat seuraavat:

1) Millaisia laadullisia eroja opettajaopiskelijoiden oppimisympäristökäsityksissä on?

2) Miten käsitykset oppimisesta kytkeytyvät erilaisiin oppimisympäristökäsityksiin?

Kuvaamme ja perustelemme aluksi tutkimuksen teoreettisen viitekehyksen. Sen jälkeen käsittelemme aiemman tutkimuksen pohjalta oppimisympäristökäsitysten, oppimiskäsitysten ja pedagogisten käsitysten keskinäisiä suhteita. Tutkimuksen analyysi ja tulokset johdattavat pohtimaan opettajankoulutuksen vaikuttavuutta.

\section{OPPIMINEN JA OPPIMISYMPÄRISTÖT}

Oppimista ja oppimisympäristöjä on pyritty jäsentämään formaalin ja informaalin oppimisen (esim. Herron \& Mendiwelso-Bendek 2018) tai informaalin oppimisen lähikäsitteen, non-formaalin oppimisen (esim. Werquin 2008) kautta. Formaali oppiminen sijoitetaan kontrolloituun, institutionaaliseen ympäristöön, ja informaali oppiminen nähdään prosessina, joka fyysisestikin sijoittuu koulutusjärjestelmän ulkopuolelle (Chang, Hagman, Chien \& Cho 2012). Tätä jakoa haastavat esimerkiksi 'ubiikki oppiminen' (esim. Hung ym. 2014) ja lisättyyn todellisuu- 
FormaAlia JA INFORMAALIA

OPPIMISTA VOIDAAN PITÄ̈̈

TOISIAAN TÄYDENT ÄVINÄ,

YHTÄAIKAISINA JATKUMOINA.

teen (augmented reality) perustuvat oppimisympäristöt (esim. Salmi, Kaasinen \& Kallunki 2012).

Informaali oppiminen näyttäytyy näin jokapäiväisessä elämässä yksilön kiinnostuksen ja aktiviteettien perusteella. Non-formaali oppiminen muodostuu formaalia oppimista täydentävistä tai sille vaihtoehtoisista oppimisen tavoista. Tässä yhteydessä käytämme käsitettä informaali oppiminen, johon myös non-formaalin oppimisen sijoitamme. Formaali oppiminen puolestaan ymmärretään koulutuksen opetussuunnitelman mukaisena ja didaktisesti suunniteltuna kokonaisuutena, johon kuuluvia oppimistilanteita voi olla sekä koulussa että sen ulkopuolella. Oppimistilanne on tällöin suunniteltu ja opetussuunnitelman mukaisia tavoitteita palveleva.

Vaikka formaali ja informaali oppiminen nähdään useissa tutkimuksissa vastakohtina, niitä voidaan ajatella toisiaan täydentävinä ja yhtäaikaisina jatkumoina (Grosemans ym. 2015). Formaalin ja informaalin tai non-formaalin oppimisen keskinäinen rajanveto koskee yhä enemmän oppimistulosten opetussuunnitelmaperusteista todistusarviointia sekä oppilaitosten valtaa ja mahdollisuutta monopolisoida tutkintojen myöntämistä (Werquin 2008).

Oppijaa kannustavassa oppimisympäristössä huomioidaan sosiaaliset ja psykologiset ulottuvuudet (Vihervaara 2009; Toom, Pietarinen, Soini \& Pyhältö 2017). Opiskelijoiden näkökulma korostaa sosiaalisen ympäristön merkitystä. Suhteet opiskelijatovereihin ja henkilöstöön ovat tärkeitä, ja ne koetaan fyysistä oppimisympäristöä merkityksellisempänä ulottuvuutena (Westling Allodi 2002; Fredricks 2011; Winding \& Andersen 2015).

Toisenlaisen näkökulman oppimiseen tarjoavat esimerkiksi informaalit sosiaalisen median kanavat, kuten vloggareiden tuottamat sisällöt Youtube-pal- velussa. Niiden tuella opitaan mitä erilaisempia sisältöjä, jotka oppija kokee mielenkiintoisiksi ja käyttökelpoisiksi (esim. Alston \& Ellis-Hervey 2015), vaikka opittujen taitojen arvo jäisi oppilaitosten tai tutkintojen näkökulmasta vähäiseksi. Sosiaalisen median yhteisöt voivat olla esimerkiksi informaalin, omaa ammattitaitoa kehittävän oppimisen alustoja (esim. Rehm \& Notten 2016).

Digitaalisuus laajentaa oppimisen mahdollisuutta niin ajan, paikan kuin roolien ymmärtämisen suhteen. Se voi osaltaan muuttaa luokkahuoneoppimisen, koulun toimintatapojen ja läsnäolokontrollin uskomuksia. Esimerkistä käyvät henkilökohtaiset digitaaliset oppimisympäristöt, jotka käyttäjä voi muovata mieleisekseen ja joiden sisällä hän voi haluamallaan tavalla jakaa digitaalisia aineistoja ja dokumentteja toisten käyttäjien ja ympäristöjen kanssa (Manninen ym. 2007, 35; Kompen, Edirisingha, Canaleta, Alsina \& Monguet 2019).

Teknologisten työskentelyalustojen lisäksi avoimien oppimisympäristöjen ja digitaalisten laajennettujen todellisuuksien asetelmat ohjaavat kohti oppilaskeskeistä toimintatapaa, vähentävät opettajan kontrollia ja muuttavat opettajan ja oppijan perinteisiä rooleja (Salmi ym. 2012). Toisaalta digitaalisten oppimisympäristöjen yhä laajempaa koulutuskäyttöä tulee tarkastella kriittisesti. Vaikka teknologia mahdollistaa ajasta ja paikasta riippumatonta oppimista, sen käyttöön sisältyy kosolti esimerkiksi oppijoiden yksityisyydensuojaa koskevia kysymyksiä. Niiden merkitys oppimisympäristöjen valinnassa on keskeinen. Teknologioiden keräämä tieto ja näin mahdollistunut vallankäyttö on osa laajaa yhteiskunnallista ilmiötä. Oppiminen voi muuttua elämyskeskeiseksi teknologiariippuvuudeksi, joka palvelee kolmannen tahon taloudellisia intressejä (Parviainen 2015).

Tuoreimmissa kotimaisissa koulutuksen uudistamispyrkimyksissä perusasteella, toisella asteella ja korkea-asteella oppimisympäristöt ovat saaneet merkittävästi painoarvoa (esim. Opetushallitus 2014; Laki ammatillisesta koulutuksesta 531/2017; Ammattikorkeakoululaki 932/2014). Opettajankoulutuksen ja työelämäyhteistyön näkökulmasta asialla on ainakin kaksi ulottuvuutta. Ensimmäinen on opettajaopiskelijoiden tulevaan professioon sisältyvä 
itsenäisen vuorovaikutusosaamisen asiantuntijuus, jolla rakennetaan yhteistyötä verkostoitumalla koulun ja oppilaitoksen ulkopuolisten tahojen kanssa (esim. Payne \& Zeichner 2017). Organisaatioiden rajapinnat ylittävä verkostoituminen edellyttää sosiaalisia taitoja, kuten yksilö- ja yhteisövastuullisuutta, itseohjautuvuutta, taitoa käynnistää ja ylläpitää dialogeja uuden ymmärryksen rakentumiseksi sekä joustavuutta. Näiden taitojen harjoittelu on vaarassa jäädä vähäiseksi akateemisten opintojaksojen formaaleissa, usein ulkoa ohjeistetuissa ja määritellyissä opetustilanteissa. (Haapakorpi 2009; Rajaniemi ym. 2018.)

Toinen ulottuvuus on oppimisprosessin paikan laajentaminen. Teorian ja käytännön rajapinnalle soveltuvien yhteistyötaitojen lisäksi opettajilla on oltava taitoja sijoittaa opetustaan fyysisen oppilaitosympäristön ulkopuolelle sijoittuviin oppimisympäristöihin. (Penttinen, Skaniakos, Lairio \& Ukkonen 2011; Hakkarainen, Lallimo \& Toikka 2012; Vesterinen ym. 2017.) Jos opiskelijalla ei ole omakohtaisia kokemuksia koulun ulkopuolisten oppimisympäristöjen mielekkäästä pedagogisesta hyödyntämisestä, omien käsitysten työstäminen voi olla hämmentävää.

\section{PEDAGOGIIKKA AVOIMISSA OPPIMISYMPÄRISTÖISSÄ}

Nykyistä avoimempien oppimisympäristöjen käyttö edellyttää pedagogisten uskomusten jäsentämistä tiedollisia edellytyksiä huomioivalla eli episteemisellä tasolla. Koulun toimintakulttuuri muuttuu ja muovaa opettajien käsityksiä omasta osaamisesta ja oppimisesta työuran aikana (Grosemans ym. 2015). Opettajuuden osaamisen jäsennystä muuttavat opetuksen rakenteen, sitä koskevan kontrollin ja oppijan toiminnallisuutta ja vastuuta painottavan lähestymistavan omaksuminen (Saltmarsh, Chapman, Campbell \& Drew 2015) sekä jaetun oppimisen painottaminen (Rehm \& Notten 2016). Käytännössä muutoksen tulisi näkyä esimerkiksi ympäristön sosiaalisen tuen rakenteissa ja ilmapiirissä (Toom ym. 2017).

Muutosta tuottaa myös informaalin oppimisen huomioiminen arvioinnissa (Bourke, O’Neill \& Loveridge 2018). Yhtäältä sen tunnistaminen ja todentaminen edellyttävät yhä monimuotoisempaa ja erityisosaamiseen perustuvaa arviointiprosessia (Werquin 2008). Toisaalta on esitetty, että informaaliin oppimiseen ei voida liittää ulkopuolista arviointia (Callanan, Cervantes \& Loomis 2011). Eriävät näkemykset arvioinnin ja informaalin oppimisen suhteesta haastavat opettajia kehittämään ja jäsentämään arviointiosaamistaan.

Informaalin oppimisen määrittelyyn sisältyvät sosiaalinen yhteistoiminta, oppijan omaan mielenkiintoon ja valintaan perustuvat oppimisprosessit ja opittavan asian kokeminen merkityksellisenä (Callanan ym. 2011). Monet mielenkiintoiset asiat sijoittuvat opetussuunnitelmien ulkopuolelle ja erityisesti mediaan (Laru 2014; Alston \& Ellis-Hervey 2015). Opettajan tulee omalla pedagogisella toiminnallaan rakentaa koulutuksen kontekstia sosiaalisesti ja akateemisesti yhä osallistavammaksi. Opettajan vuorovaikutustaidoilla ja sopivien oppimisympäristöjen hyödyntämisellä tuetaan oppimisen henkilökohtaisten merkitysten löytämistä ja sen seurauksena koulutukseen sitoutumista. (Fredricks 2011.)

Oppilaitoksen ulkopuolinen toiminta edellyttää opettajalta valmiutta siirtyä perinteisen oppiainedidaktisen osaamisalueensa reuna-alueille tai jopa niiden ulkopuolelle. Yhteistyökumppaneiden kanssa työskennellessään opettajan tulee olla valmis ylittämään rajoja, joita opettajan ja yhteistyötoimijan välille on ajateltu muodostuneen. Opettajien tulee kyetä esimerkiksi uusiin moniäänisiin vuorovaikutuksen tapoihin ja riittävän toimintakyvyn kehittämiseen, jotta hän voi toimia eri käytänteitä omaksuneiden toimijoiden kanssa innovatiivisissa, uusia merkityksiä luovissa neuvotteluissa (Vesterinen ym. 2017; Karila, Turtiainen \& Ukkonen-Mikkola 2015; McGivern 2014; Rajaniemi ym. 2018). Yllättävät tilannetekijät ja yhteistyöverkostojen tarpeet voivat edellyttää rohkeitakin rajanylityksiä. Yhtenä opettajan toimintaa koskevana tutkimuskohteena on nostettu esiin opettajan toiminta oman osaamiskenttänsä ulkopuolella. Tällä out-of-field-näkökulmalla tarkoitetaan oman oppiaineen tai itselle tutuiksi koettujen vuosiluokkien ulkopuolelle sijoittuvaa opetusta. (du Plessis 2015.)

Teknologisista ympäristöistä keskusteltaessa opettajan pedagoginen päätöksenteko voi koskea esimerkiksi digitaalisuuden mahdollistamista tai ra- 
joittamista. Aktiivinen opetusteknologian lisääminen opettajankoulutuksen opintojaksoihin vaikuttaa opiskelijoiden teknologiatietoisuuteen ja pedagogisten ratkaisujen tekemiseen (Sointu ym. 2016).

Työelämän näkökulmasta olennaista on tarkastella opettajan taitoja ja mahdollisuuksia sisällyttää teknologiaa opetukseen nimenomaan tarve- ja asialähtöisesti. Onko koulutusjärjestelmän pedagogisena tavoitteena nähdä oppija vastuun ottajana ja opettaja aktiivisena muutostoimijana suhteessa oppijan ymmärryksen ja oppimisprosessin rakentumiseen ja omistajuuteen? Tavoitteiden suuntautumista vain teknologialähtöiseen ajatteluun pidetään ongelmallisena, koska tällöin keskitytään pelkkään teknologisten ratkaisujen käyttötaitoon tarkkaan määritellyssä oppimisympäristössä, ja pohdinta teknologian pedagogisesta mielekkyydestä voi jäädä vähäiseksi. (Kerosuo 2014; Laru 2014; Parviainen 2015.) Vaikka teknologiset oppimisympäristöt mahdollistavat joustavaa oppimista, niiden käyttöön sisältyy paljon ongelmia suhteessa esimerkiksi lasten ja nuorten osallisuuteen ja tasa-arvoon (Mertala 2019).

Koska oppiminen voidaan ymmärtää uudistuvaan työelämään tai dynaamiseen kansalaisuuteen tähtäävänä välinearvona (esim. Eikeland 2012; Kumpulainen \& Mikkola 2015), opettajuuden tulee mahdollistaa oppilaitoksen ja ympäröivän yhteisön keskinäistä ja vastavuoroista vuorovaikutusta (Hakkarainen 2017; Menary \& Kirchhoff 2014; Eikeland 2012; OKM 2016). Samalla opettajuus- ja oppimisympäristökeskustelussa on syytä tiedostaa oppimispuheen taustalla vaikuttavia poliittisia ja taloudellisia intressejä, joiden lähtökohdat eivät välttämättä palvele oppijoita tai heidän omia tarkoitusperiään (esim. Biesta 2006), ja oppimistarpeita perustellaan lähinnä yhteiskunnan ja työelämän tarpeilla (Saari 2018).

\section{TUTKIMUKSEN AINEISTO JA ANALYYSI}

Tutkimuksessamme etsimme oppimista koskevien käsitysten välisiä variaatioita suhteessa oppimisympäristökäsityksiin. Variaatioiden määrittäminen paljastaa opettajan työhön sisältyviä käsitteellisiä jännitteitä, joita opiskelijat opettajankoulutuksen loppuvaiheessa nostavat esiin.
Keräsimme opettajaopiskelijoiden käsityksiä koulun ulkopuolisesta oppimisesta "Kasvatus kestävään tulevaisuuteen” -opintojaksolla keväällä 2017. Jakso sisältyy opettajan pedagogisiin opintoihin, ja opintojen kulkukaaviossa se on sijoitettu opintojen loppuvaiheeseen. Osallistujat valmistuvat aineenopettajiksi, luokanopettajiksi, erityisopettajiksi ja opinto-ohjaajiksi. Opintojakso oli tuolloin mahdollista suorittaa myös englanniksi.

Aineistoa kerättiin opintojakson laajaan loppureflektointiin sisältyvällä avoimella kysymyksellä, joka oli pakollinen osa opintoja. Reflektointi kerättiin sähköisellä lomakkeella, mutta sitä ei käytetty opintosuorituksen numeeriseen arviointiin. Lomakkeessa jokaiselta opiskelijalta kysyttiin lupaa käyttää reflektointia tutkimusaineistona. Avoin kysymys oli seuraava: "Millaisena näet oppimisen koulun ulkopuolisissa ympäristöissä?” Reflektointitehtävän tuottaman aineiston pohjalta tutkimme, millä tavoin vastauksissa tuotettiin oppimista koskevien käsityksen eroja erityyppisissä oppimisympäristöissä ja millaisena rakenteena variaatio ilmeni.

Kaikkiaan 182 henkilöä palautti ennen analyysivaiheen alkua loppureflektoinnin, ja heistä 150 antoi suostumuksensa vastausten sisällyttämisestä tutkimusaineistoon. Kuusi vastausta oli englanninkielisiä. Luvan antaneista neljä ei ollut vastannut avoimeen kysymykseen ollenkaan. Aineistosta poistettiin kolmen sanan mittaiset ja sitä lyhyemmät vastaukset, joita niitäkin oli neljä. Lopullinen analysoitava aineisto käsitti 142 vastausta.

Opiskelijoiden vastaukset avoimeen kysymykseen vaihtelivat niukasta yhden sanan "Mitä?"-vastauksesta pidempiin, yli 100 sanan pohdintoihin. Vastaukset kuvasivat rikkaimmillaan monipuolisesti oppimisen suhdetta oppimisympäristöön ja opettajuuden monimuotoisuuteen.

Opiskelijat olivat opintojakson tehtävänä tuottaneet ryhmissä sähköistä oppimateriaalia oppilaitoksen ulkopuoliselle toimijalle, kuten järjestölle, yritykselle tai urheiluseuralle. Ryhmiin tultiin eri pääaineista. Opiskelijoilta edellytettiin osallistumista yhteistyökumppanin toimintaan, ja he kokeilivat materiaaliaan autenttisessa yhteistyökumppanin ympäristössä. Työn toteuttaminen vaati kontaktien 
solmimista koulun ulkopuolelle, neuvottelutaitoja ja yhdessä tekemisen valmiuksia (vrt. Virtanen \& Tynjälä 2013; Rajaniemi ym. 2018). Samoja taitoja heiltä odotetaan työssään.

Opintotehtävä ohjasi opiskelijoita sekä miettimään kulloisenkin toimijan tarpeita oppimisen näkökulmasta ja omia keskinäisiä uskomuksiaan oppimisesta koulun ulkopuolella että käymään reflektiivisiä keskusteluja. Tutkimuksellisesti kiinnostavaa olikin, miten laajasti reflektoinnin laajuus ja syvällisyys vaihtelivat.

Tulosten tulkinnassa on syytä painottaa sitä, että opintotehtävä oli opiskelijoille opintosuoritus, joten he ovat voineet kokea vastaamisen ja sitä koskevan kontrollin painetekijänä tai pelkkänä suorittamisena. Reflektoinnin pakollisuus on osaltaan voinut tuottaa niukkoja tai pinnallisia vastauksia, kuten "Onnistuessaan erittäin virkistävää ja avaa uusia näkökulmia”.

Analyysi pohjautui fenomenografiseen lähestymistapaan. Siinä etsitään aineistosta käsityksiä, käsitysten eroavuuksia ja ulottuvuuksia, jotka eroja tuottavat (Marton \& Booth 1997; Sin 2010). Analyysin tuloksena on variaatioiden rakenne ( $\AA$ kerlind 2005), jolla kuvataan käsitysten keskinäistä hierarkiaa rajatusta käsityksestä kohti laajaa ja monipuolista käsitystä (Uljens 1989). Analyysiyksikkönä oli käsityksen kuvaus eli teksti, jossa kuvataan oppimista liitettynä oppimisympäristöön ja asiaan liittyviä määritteitä. Yksittäinen vastaus voi tällöin sisältää useita keskenään ristiriitaisiakin käsityksiä (Uljens 1989). Kapeimmillaan koko vastaus muodosti yhden toteavan käsityksen. Monipuolisimmillaan yksittäiseen vastaukseen sisältyi kahdeksan eri näkökulmaa

\begin{tabular}{|c|c|}
\hline Oppimisympäristö & Esimerkkejä analyysiyksiköistä \\
\hline \multirow{3}{*}{$\begin{array}{l}\text { Oppimisen } \\
\text { ympäristö on } \\
\text { lähtökohtaisesti } \\
\text { koulussa, ja käsitys } \\
\text { laajempien oppimis- } \\
\text { ympäristöjen } \\
\text { käytöstä on } \\
\text { varauksellinen. }\end{array}$} & $\begin{array}{l}\text { "Koulun ulkopuoliset oppimisympäristöt voivat olla opettajalle haasteellisia etenkin } \\
\text { yksilöiden kehittymisen ja työmäärän arvioinnin kannalta" (57) }\end{array}$ \\
\hline & $\begin{array}{l}\text { "Kyllähän koulun pitää muuttua yhteiskunnan mukana, mutta toisaalta jos yhteiskunta } \\
\text { muuttuu tietyllä tapaa levottomampaan suuntaan, niin eikö tietty ennalta-arvattavuus ja } \\
\text { tuttuus ole koulussa myös hyväksi?" (102) }\end{array}$ \\
\hline & $\begin{array}{l}\text { "Haastavana sekä stressaavana. Tänä päivänä vähennetään työntekijöitä, mutta työn määrä } \\
\text { pysyy entisellään tai lisääntyy." (123) }\end{array}$ \\
\hline \multirow{4}{*}{$\begin{array}{l}\text { Oppiminen } \\
\text { kontekstoidaan } \\
\text { suhteessa formaaliin } \\
\text { kouluoppimiseen } \\
\text { ja laajemmat } \\
\text { oppimisympäristöt } \\
\text { käsitetään oppimis- } \\
\text { prosessia tukeviksi } \\
\text { ja rikastaviksi } \\
\text { resursseiksi. }\end{array}$} & $\begin{array}{l}\text { "Näen sen resurssina, mutta myös välttämättömyytenä, ettei koulussa tapahtuva opetus } \\
\text { kärsi epäkontekstuaalisuudesta." (10) }\end{array}$ \\
\hline & $\begin{array}{l}\text { "Oppimista ei tapahdu ainoastaan koulussa, vaan oppia voi missä tahansa. Tämän vuoksi } \\
\text { on mahtavaa, että uusissa opetussuunnitelmissa oppimisympäristön käsite on laajentunut ja } \\
\text { oppilaille tarjotaan mahdollisuuksia oppimiskokemuksiin myös koulun ulkopuolella." (11) }\end{array}$ \\
\hline & $\begin{array}{l}\text { "Mielestäni koulun ulkopuolisia oppimisympäristöjä tulisi hyödyntää enemmänkin } \\
\text { opetuksessa. Minusta koulun ulkopuoliset oppimisympäristöt ovat usein hyvin mielekkäitä } \\
\text { ja innostavia oppilaille." (131) }\end{array}$ \\
\hline & "Näen sen kuitenkin enemmän mahdollisuutena kuin uhkana!" (169) \\
\hline \multirow{3}{*}{$\begin{array}{l}\text { Oppiminen on } \\
\text { jatkuva prosessi, } \\
\text { joka on mahdollista } \\
\text { kaikkialla. }\end{array}$} & $\begin{array}{l}\text { "Oppiminen kuitenkin alkaa varmaan jo syntymässä (tai ehkä jo kohdussa ollessa?) ja voisin } \\
\text { olettaa oppimisen jatkuvan aina kuolemaamme saakka." (25) }\end{array}$ \\
\hline & $\begin{array}{l}\text { "Uskon myös lujasti elinikäisen oppimisen käsitteeseen. Oppiminen ei yhtäkkiä lakkaa siinä } \\
\text { vaiheessa, kun esimerkiksi koulu loppuu tai valmistuu yliopistosta maisteriksi. Tohtoriksi } \\
\text { väitellytkään ei ole muuttunut täydelliseksi asiantuntijaksi edes oman kapean osaamisalueensa } \\
\text { suhteen, vaan siitäkin riittää loputtomasti opittavaa, vaikka jo hirmuisesti olisikin opittu." (95) }\end{array}$ \\
\hline & $\begin{array}{l}\text { "Oppiminen koulun ulkopuolisissa ympäristöissä on osa elinikäistä oppimista. Ihminen } \\
\text { kasvaa ja kehittyy tai muuten muuttuu koko elämänsä ajan saamalla erilaisia ärsykkeitä } \\
\text { ulkopuolisesta maailmasta."(158) }\end{array}$ \\
\hline
\end{tabular}

Taulukko 1. Analyysin kategorioiden määrittyminen. 


\section{OpetTaja OPISKELIJOIDEN}

\section{ÄÄNI EI OLLUT YHTENÄINEN.}

kuvaavaa käsitystä. Useita käsityksiä sisältävät vastaukset olivat reflektiivisiä ja vertailevia.

Kirjallisessa muodossa olevat vastaukset jaoteltiin analyysiyksiköihin, jotka puolestaan jaettiin oppimisympäristökäsityksen mukaan kolmeen kategoriaan. Työssä käytettiin laadullisen aineiston käsittelyä helpottavaa NVivo-ohjelmaa. Koodauksen ensimmäisen vaiheen (taulukko 1) jälkeen analyysi jatkui etsimällä ja vertailemalla kategorioiden sisältämiä oppimiseen ja oppimisympäristöihin liittyviä käsityksiä.

Yksikään vastaus ei kieltänyt koulun ulkopuolisten oppimisympäristöjen käyttömahdollisuutta. Opiskelijat pitivät "hyvänä mahdollisuutena" useita oppimisympäristöjä, kuten kierrätyskeskusta, maatilaa, peliä tai koulun pihaa tai niiden yläkäsitteitä, esimerkiksi avointa ympäristöä tai sähköisiä ympäristöjä. Omakohtaisia opetuskokemuksia opiskelijat pitivät vähäisinä, ja vastaajat kokivat opintojakson tehtävän sijoittamisen koulutusjärjestelmän ulkopuolelle uutta näkökulmaa tuovana ratkaisuna.

Aineistossa oli sisäisiä laadullisia eroja, jotka fenomenografisella tutkimuksella pyritään havaitsemaan (Sin 2010). Opettajaopiskelijoiden ääni ei ollut yhtenäinen, ja siksi on tärkeää tutkimuksellisesti jäsentää sitä, minkälaisia eroavuuksia käsityksistä on löydettävissä.

"Sähköisistä oppimisympäristöistä en niin paljon välitä niiden muutamien kokemusten pohjalta, joita minulla on." (Vastaus 54)

"Tulen käyttämään omassa opetuksessa mahdollisimman paljon digitaalisia ympäristöjä." (Vastaus 147)

Vastaajan oma oppiminen kuvautui oman oppimisprosessin ja opettajuuden kehittämistä edistävän oppimisen näkökulmasta ja käsityksen mukaisen oman tulevan työn kautta. Oma tuleva työ sijoittui pääsääntöisesti perusopetukseen ja lukioon. Käsityksiä kolmannesta sektorista tulevana työnä oli tulkinnasta riippuen muutamia.

\section{TULOKSET}

Suppeimmillaan opiskelijat käsittivät oppimisen sulkeutuneen koulujärjestelmän sisäisenä prosessina ja laajimmillaan elämänlaajuisena olemassaolon tapana. Näiden keskelle muodostuu formaalia koulutusta ja informaalia oppimista yhdistävä käsitys, jossa oppiminen käsitettiin suhteessa avautuvaan koulutusjärjestelmään. Fenomenografisen lähestymistavan mukaan tulos esitetään oppimisen ja oppimisympäristön suhteita ja niiden välisiä eroja kuvaavana hierarkkisena variaatioiden rakenteena (kuvio 1).

Tulosten esittely etenee kapeasta käsityksestä kohti laajempaa käsityskuvausta. Olemme sijoittaneet tekstiin aineistokatkelmia analyysiprosessin kuvaamiseksi. Vastausten numeroinneilla kuvaamme aineistokatkelmien sijoittumista vastauksiin ja laajemmin koko aineistoon.

\section{Oppiminen sulkeutuneessa koulutusjärjestelmässä}

Kun oppimisympäristöä määriteltiin järjestelmään rajautuvaksi, fyysistä ympäristöä kuvaavana sanana oli 'koulu' tai 'luokkahuone'. Usein oppimiskäsityksen pohjalla oli lähtökohtainen oletus opettajajohtoisen luokkatilanteen luontevuudesta ja helppoudesta. Vaikka koulun ulkopuolinen opetus koettiin sinänsä mahdollisena, koulu kuvautui oppimisen oletettuna sijaintipaikkana, ja oppiminen rakentui lähtökohtaisesti koulussa.

"Koulu pistää oppimisprosessin käyntiin ja se jatkuu koulun ulkopuolella." (Vastaus 180)

Ulkopuolisten oppimisympäristöjen hyödyntäminen oli siis "toteuttamisideana hyvin mahdollinen", mutta niiden hyödyntäminen oli "haastavaa ja stressaavaa".

"Yhteistyöjutut ovat aina melko raskaita." (Vastaus 127)

Mielenkiintoista oli havaita resurssipuhe osana oppimisympäristöjen laajentamisen kuvailua. Koulun ulkopuolelle lähdettiin vain "resurssien riittävyyden mukaan". Resurssin puuttumista pidettiin rajoittavana haasteena koulun ulkopuolisten oppimisym- 


\section{RESURSSIN PUUTTUMISTA}

\section{PIDETTIIN RAJOITTAVANA}

\section{HAASTEENA KOULUN}

\section{ULKOPUOLISTEN}

OPPIMISYMP ̈̈RISTÖJEN

HYÖDYNT $\ddot{M} I S E S S \ddot{A}$.

päristöjen hyödyntämisessä. Puuttuvan resurssin käsitettä ei vastauksissa avattu. Laajoja oppimisympäristöjä sen sijaan ei tämän kategorian käsityksissä nähty resurssina.

Kategorian kuvauksissa opettajan rooli pysyi kyseenalaistamattomana. Opettajan työn muutokseen viitattiin vain ulkopuolisten oppimisympäristöjen tuottamana kasvavana haastavuutena ja kuormittavuutena. Mikäli vuorovaikutustaidot luetaan opettajan työelämätaitoihin, opettajaopiskelijoiden kokemat vaikeudet verkostojen rakentamisessa voivat vaikuttaa jopa yllättäviltä. Aineistoon sisältyi suorasanaisia esimerkkejä.

"Mielestäni on vain vaikeaa tehdä aloitteita joihinkin ryhmiin / organisaatioihin, jos suhteita ei ole." (Vastaus 182)

Opettajankoulutuksen näkökulmasta mielenkiintoista on pohtia opetusharjoittelun osuutta. Aineisto ei sisältänyt käsityksiä, joissa harjoittelu olisi aktiivisesti tukenut avoimien oppimisympäristöjen käyttöä. Varauksellisten käsitysten yksi tulkinta voi olla, että harjoittelu tarjoaa ilmeisen vähän reflektoituja oppimisympäristöön keskittyviä kokemuksia. Näin asia jää käsittelemättömäksi.

"Olen hyvin avoin myös muille ympäristöille, mutta esimerkiksi harjoitteluissa niiden kokeilu on jäänyt vähälle." (Vastaus 66)

Kun opiskelijan käsitys oppimisesta painottuu vahvasti formaaliin kouluoppimiseen ja luokkahuoneeseen oppimisympäristönä, ei monipuolisten oppimisympäristöjen käytössä tarvittavaa osaamista tule aineistossa näkyville.

\section{Oppiminen avautuvassa koulutusjärjestelmässä}

Tämän kategorian käsityksissä siirryttiin kohti edellistä katergoriaa avoimempaa ympäristöä, ja vastauksissa korostui päätöksenteon ja opetussuunnitelmaperustaisen ajattelun merkitys. Koulun ulkopuolisista oppimisympäristöistä haettiin aineksia, joilla voitiin "rikastuttaa" luokkaopetusta. Kirjoituksissa puhuttiin vaihtelevuuden tuottamisesta sekä käytännön ja konkretian tavoittamisesta. Teoreettinen oppiminen sidottiin kouluun, kun taas soveltaminen ja arkiosaaminen sijoitettiin koulun ulkopuolelle.

Vierailujen hyödyntäminen liitettiin tiettyihin oppiainesisältöihin. Valintapäätökset teki opettaja, ja päätöksentekoa ohjasi oppiaineen oppisisältö. Siten oppiminen oli edelleen yhteydessä nimenomaan koulutuksen oppiainesisältöön, mutta samalla koulun ulkopuoliset ympäristöt olivat merkittäviä kokemuksellisuuden rakentajia tai oppimista vahvasti monipuolistavia ja tukevia ympäristöjä. Laajoja oppimisympäristöjä pidettiin oppimisen resurssina. Vierailujen antia hyödynnettiin kouluopetuksessa.

"Olen äidinkielenopettaja, joten luontevasti tulevat mieleen ainakin kirjastot, mediatalot ja teatterit. Ja jos käydään jossain, niin seuraavalla tunnilla mietitään koettua vielä koulussa.” (Vastaus 102)

Aineiston analyysi tuotti kuitenkin myös ristiriitaisia mielikuvia. Samalla kun koulun ulkopuolisten oppimisympäristöjen arvoa korostettiin, tultiin tuottaneeksi käsitys opettajan oman oppimiskäsityksen painottumisesta koulutuksen formaaliin oppimiseen. Formaali ja informaali oppiminen erotettiin toisistaan. Lähtökohdaksi koettu oppimisprosessin sitominen oppiaineeseen liitettiin formaaliin luokkahuonetyöskentelyyn, ja avoimen oppimisympäristön hyödyntämisen rooli oli tukea luokkahuonetyöskentelyä.

Koulun ulkopuoliset oppimisympäristöt käsitettiin motivoiviksi. Oppimisen näkökulmasta tärkeää oli "lapsien mielenkiinnon herääminen, luovuus", ja oppimisen tueksi saatiin "enemmän aisteja mukaan". Opiskelijoiden käsitysten mukaan oppimisen monikanavaisuus tuki erityisesti niitä oppilaita, joille lukeminen oli vaikeaa. Koulun ulkopuolella oppiminen 
käsitettiin soveltavaksi ja oppiainerajoja rikkovaksi.

Kun opetusta siirrettiin koulun ulkopuolelle, opettajan ja oppijan roolit alkoivat laajentua ja muovautua uudelleen. Opettajan tehtäväksi nähtiin oppiainedidaktisen toiminnan lisäksi oppimisen metataitojen tunnistaminen, havaitun osaamisen eksplikoiminen, oppimiseen innostaminen sekä oppilaiden rohkaiseminen omien kokemustensa hyödyntämiseen oppimisprosesseissa. Oppimisen omistajuus alkoi siirtyä oppijalle. Vastauksissa oletettiin, että oppilaat eivät välttämättä arvosta koulun ulkopuolella heränneitä oivalluksia yhtä paljon kuin esimerkiksi koetuloksia. Siksi opettajan rooliin sisällytettiin pyrkimys ohjata lapsia tunnistamaan oppimista laajemmin, ja oppimisen pitkää jatkumoa korostettiin.

Koulun avautuminen näkyi halukkuutena muokata kouluympäristöä. Aineistossa oli viittauksia digitaalisiin oppimisympäristöihin, joita koulussa voitaisiin hyödyntää.

"[--] myös kouluun voi luoda sellaisia oppimisympäristöjä joissa ulkopuolisten oppimisympäristöjen hyvät ansiot toteutuvat." (Vastaus 49)

Joissakin käsityksissä koulua pidettiin oppilaan kaiken kattavana elämänpiirinä. Jos koulu vastaa koulun ulkopuolisen "oikean elämän" kokemusten saamisesta, on syytä tarkastella ajattelun koulukeskeisyyden perusteluja ja paradoksaalisuutta.

”Lisäksi olisi tärkeä saada kokemuksia ns. 'oikeasta elämästä' ja yhteiskunnasta ennen kuin aloittaa peruskoulun jälkeiset opinnot esimerkiksi ammatillisessa oppilaitoksessa." (Vastaus 172)

Yhtältä kyse on kaikille yhteisten oppimiskokemusten ja oppimisympäristöjen laajentamismahdollisuuksista. Toisaalta koulu määrittyy muusta maailmasta irralliseksi kontekstiksi, ja oppijan omaan arkeen sijoittuvan "oikean elämän” arvo kyseenalaistuu.

\section{Oppiminen olemassaolon tapana}

Kun oppimisympäristöjä pidettiin täysin avoimina, kuvaus eri toimijoiden rooleista muuttui ratkaisevasti. Oppija nähtiin valintapäätösten tekijänä sekä oppimisprosessin vastuullisena ja aktiivisena toimijana.
Oppiminen hahmottui koko elämän kattavaksi ilmiöksi, ja oppimista tapahtui kaikkialla.

Oppiminen olemassaolon tapana -kategoriaan liittyi oppiminen, joka tapahtui "huomaamatta", "tiedostamatta" ja jopa "salakavalasti". Opettajan rooli muuttui vain yhdeksi oppimisen ohjaajaksi ja tukijaksi. Koulun ulkopuolella "ei voi olla perinteinen opettaja". Oppijan henkilökohtainen ja suora suhde oppimisympäristöön tuotti oppimiskokemuksia. Oppijan rooliin sisällytettiin aktiivinen tiedon etsiminen.

Osin vastauksissa jatkui jako oppilaitoksen ulkopuoliseen ja sisäiseen oppimisympäristöön. Luokkahuoneisiin sijoittuvaan "perinteiseen" opetukseen kohdentui kritiikkiä. Vertailu korosti koulunkäyntiä pakkotahtisena ja koulujärjestelmän ulkopuolella tapahtuvaa oppimista vapaana ja itsesäädeltynä. Koko oppimisen käsite koulutusjärjestelmän ulkopuolelle sijoittuneena tulikin täten ymmärtää toisin. Vapaaehtoisuutta pidettiin koulun ulkopuolisessa oppimisessa ensisijaisena. Siksi oppimistilanteet eivät saaneet edes muistuttaa koulukulttuurista.

"Oppiminen ei saa missään nimessä muistuttaa kouluopiskelua ja pänttäämistä, mikäli kyse on kuitenkin vapaaehtoisesta opiskelemisesta." (Vastaus 162)

Kun oppimisympäristö nähtiin laajana, ja oppija sai itsenäisesti vaikuttaa siihen, miten ja mitä hän kulloinkin oli oppimassa, opittu käsitettiin omakohtaisena. Oppija teki kaikki valinnat, sääteli oppimiseen käytettyä aikaa ja omisti oppimisprosessinsa kokonaan. Opittu jäsentyi suhteessa omiin tarpeisiin ja tavoitteisiin, eikä pohdinta ulottunut koulunpidon asettamiin reunaehtoihin.

"Opit, kun hankit uutta tietoa, ymmärrät sitä ja teet siitä omaasi." (Vastaus 73)

Laajan oppimisympäristöajattelun kuvaukset sisälsivät pieniä anekdootteja vastaajien omilta oppimispoluilta. Esiin otettiin työelämään ja harrastuksiin sijoittuvaa kokemuspohjaista oppimista. Oppimista koulun ulkopuolella pidettiin laajempana, syvempänä ja merkityksellisempänä kuin kouluoppimista. Koulun ulkopuolisuus yhdisti oppimisen kokemuksiin stressittömyyttä, ystävyyttä ja pakottomuutta. 


\section{K OULUN ULKOPUOLISUUS}

\section{YHDISTI OPPIMISEN}

\section{KOKEMUKSIIN}

\author{
STRESSITTÖMYYTT ̈̈, \\ YST ̈̈VYYTT ̈̈ JA \\ PAKOTTOMUUTTA.
}

Avointen oppimisympäristöjen tiukimmin rajautuneissa kuvauksissa opiskelijat rajasivat koulujärjestelmän suorasanaisesti vastausten ulkopuolelle. Kirjoittaja esimerkiksi nimenomaisesti korosti oppimisympäristöjä, jotka oli rakennettu "ei-koulussaoleville”. Jos näihin ympäristöihin, kuten peleihin, oli hakeuduttu itsenäisesti, niissä käsityksen mukaan opittiin aina jotain.

"[--] esim. peleissä täytyy olla paljon parempi kielitaito kuin mitä koulussa ehtii oppia, joten neljäsluokkalaisen englannin sanavarasto on paljon laajempi kuin enkunkirjan kappaleet." (Vastaus 68)

Opiskelijoiden esittämät oppijan ja opiskelun suhteeseen liittyvät käsitykset voivat olla opettajan ammattia ajatellen hankalia. Aineiston esimerkit liittyivät yksittäisiin oppijoihin. Vaarana onkin, että opettajan ammatillinen oppimiskäsitys perustuu yksittäisiin oppilasoletuksiin. Kaikki eivät pelaa sähköisiä pelejä, ja on vaikeaa osoittaa, että aivan kaikki pelaajatkaan oppisivat englantia omaa ikäryhmäänsä enemmän.

Toisaalta peliympäristössä opitun kielen vertaaminen opetussuunnitelman sisältöön tai lingvistisesti orientoituneeseen kielenoppimiseen ei ehkä kuulu asiaan lainkaan, koska asiaa lähestyttiin tämän kategorian vastauksissa avoimen oppimisympäristön näkökulmasta. Siksi koulujärjestelmäkeskeisen ajattelun kysymykset siitä, minkälaista englantia pelit opettavat ja missä määrin opittu englanti on hyödynnettävissä kouluoppimisessa, voivat olla pelaajan näkökulmasta absurdeja.

Oppimisen sosiaalinen konteksti nostettiin tässä kategoriassa esiin. Oppimisprosessia vahvistivat varsinaisen opettajan ja hänen valitsemiensa oppimis- ympäristöjen lisäksi vanhemmat, ohjaajat, valmentajat, ystävät ja muut toimijat. Samalla uudelleen määrittyneeseen opettajuuteen ja aikuisuuteen yhdistyi uusia piirteitä. Opettajat olivat myös oppimassa. Roolien muovautumisen myötä oppiminen muuttui yhtäältä ihmisten keskinäisiksi ja toisaalta ihmisten ja ympäristöjen välisiksi dialogisiksi suhteiksi, joissa muodostui monenlaista uutta tietoa ja osaamista. Edelleen taustalla vaikutti koulukeskeisyys, joka nostettiin esiin vertailukohtana ja toisaalta oman tulevan työssäoppimisen kenttänä.

"Ihmiset oppivat varmaankin esimerkiksi seuraamalla sitä, mitä muut ihmiset tekevät." (Vastaus 25)

”Eikä pidä unohtaa aikuisten itsekin oppivan koko ajan uusia asioita, vaikkeivat enää koulussa olisikaan." (Vastaus 173)

"Kaikkia oppia ei saa koulusta - ja monesti esimerkiksi sanotaankin, että tärkein oppi tapahtuu työpaikalla." (Vastaus 85 )

Joissakin pohdinnoissa koulutusjärjestelmän kokonaistavoitteeksi nähtiin oppijan omien oppimismahdollisuuksien tiedostaminen, oppimaan oppiminen ja jatkuvan oppimisen rakentaminen osaksi koko elämänkaarta. Koulun ulkopuolella ”oppiminen tarjoaa mahdollisuuden harjoitella sellaisia toimintamalleja, mitä ns. normiopetuksessa ei pystytä toteuttamaan, mutta mistä voi olla hyötyä myöhemmin elämässä”.

Oppimisen tuli kehittää henkilökohtaista kasvua ja palvella yhteiskuntaa ja maailmaa. Sen ideana on "valmentaa ja antaa taidot lapsille kasvaa tasa-arvoiseksi ja hyödylliseksi kansalaiseksi muuttuvassa ja moninaisessa yhteiskunnassamme”. Käsitykset liittyivät oppimisen jatkumoon koulutusta pidempänä prosessina, ja tätä jatkumoa osattiin käsityksissä kuvata yksityiskohtaisemminkin.

"Oppimista ei voi rakentaa vain koulussa tapahtuvaksi, vaan oleellisen tärkeää, on että oppiminen muodostuisi elinikäiseksi elämäntavaksi. Koulun tehtävänä on yhä enemmän vain antaa työkaluja ja aktivoida oppimaan oppimiseen, tukea kunkin yksilöllistä tapaa oppia ja löytää omat väylät ja kanavat siihen." (Vastaus 48) 
Tässä käsitekategoriassa formaali ja informaali oppiminen muodostivat jatkuvasti kehittyvää kokonaisuutta. Opettajan ja koulutuksen tehtävänä oli tukea oppijan omassa elinpiirissä rakentuneiden osaamisalueiden tietoista hyödyntämistä osana oppimisprosesseja.

\section{Tulosten yhteenveto}

Oppimiskäsitykset rakentuivat sisäkkäisiksi (kuvio 1). Laajempaankin oppimiskäsitykseen sisältyvää kuvausta verrattiin kehän sisempiin kerroksiin. Kun oppiminen sisimmällä kehällä kuvautui oppiainekeskeisenä, niin uloimmalla oppiminen olemassaolon tapana -kehällä esillä olivat vahvasti oppijan omaa aktiivisuutta, oman osaamisen jatkuvaa kehittämistä, oppimisen laajuutta ja metataitoja koskevat käsitykset.

Liikuttaessa sisäkehältä kohti ulkokehää käsitysten painotus muuttui usealla eri ulottuvuudella. Sisimmän kehän opettajakeskeisestä tekstistä siirryttiin oppijakeskeiseen sisältöön, opettajan kontrollivastuun rinnalle kehittyi oppijan oma vastuu, ja oppiainesisällön painotus vaihtui oppimisen metataitojen korostamiseen.

Koska mallin avulla voidaan käsitellä erilaisia opettajien oppimiskäsityksiä ja niiden suhdetta oppimisympäristöön, sen avulla on mahdollista reflektoida kouluyhteisön tai opettajakunnan käsityksiin sisältyviä ristiriitaisuuksia tai ammatillisen kehittymisen tavoitteita. Käsityksen monipuolinen argumentointi edellyttää reflektiivistä ajattelua.

Samalla kehämalli havainnollistaa käsitysten kehittymistä osana opettajan ammatillista kasvua. Kun opiskelijan näkökulma keskittyi sisimpään, sulkeutuneen koulutusjärjestelmän puheeseen, ulompia kehiä ei ollut ollenkaan näkyvillä tai ne koettiin keinotekoisiksi ja oppimisen kannalta turhiksi tai hankaliksi. Käsityksen laajentuessa sisemmät käsitykset olivat olemassa, ja vastauksissa tuotettiin kuvauksia oman ajattelun kehittymisestä juuri sisemmältä kehältä ulommalle kehälle etenevässä järjestyksessä.

\section{POHDINTA}

Opettajaopiskelijoiden käsitykset vaihtelevat kouluympäristöön sulkeutuneesta oppimiskäsityksestä koko elämän kattaviksi. Silloinkin kun oppimisen ja oppimisympäristön suhde nähtiin laajana ja koko elämän kattavana, nostettiin koulusidonnainen näkökulma usein vertailukohdaksi. Tällöin tiukasti koulutusinstituution tiloissa tapahtuva oppiminen nimettiin vanhanaikaiseksi tai perinteiseksi.

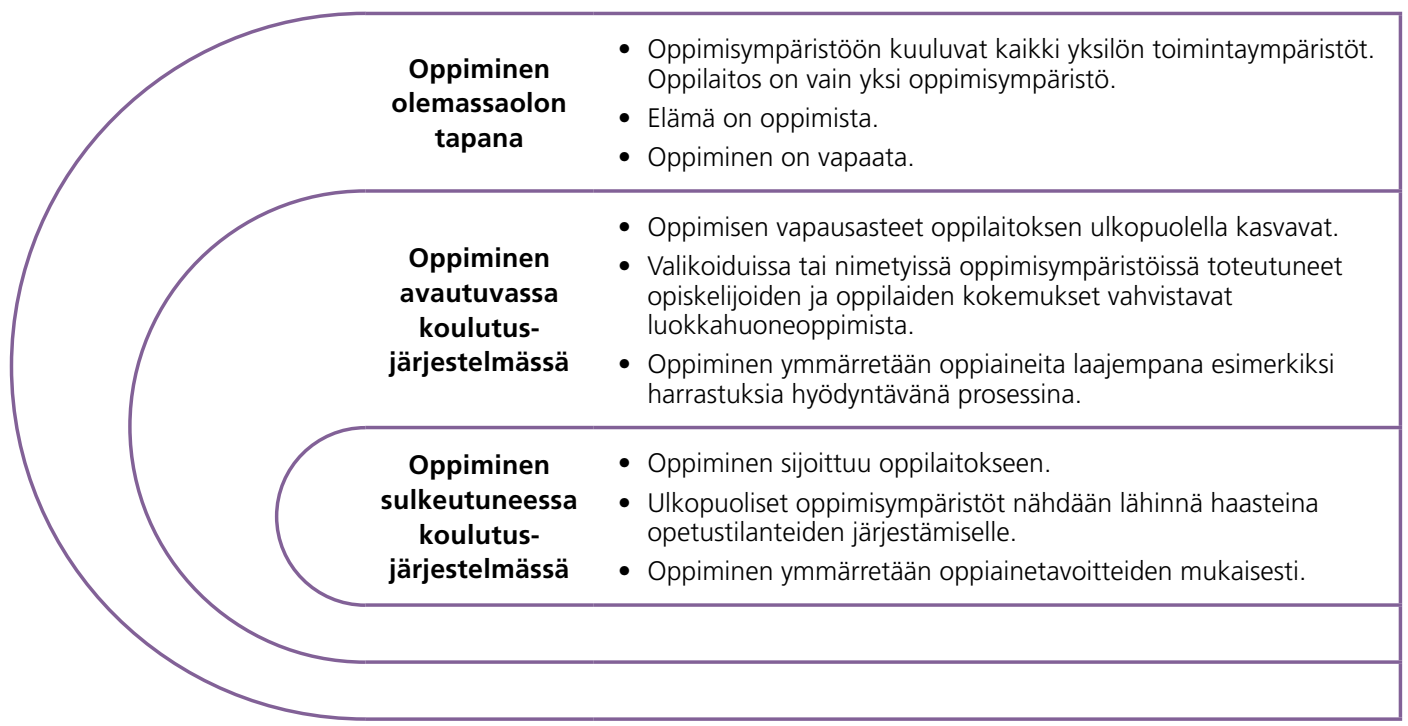

Kuvio 1. Oppimisen ja oppimisympäristön suhdetta koskevien käsitysten variaation rakenne. 


\section{OPETTAJAOPISKELIJOIDEN \\ MONIPUOLISIMMAT}

\section{VASTAUKSET}

\section{KUVASIVAT VALMIUTTA \\ TOIMINTAKULTTUURIN}

KYSEENALAISTAMISEEN.

Kuten aiemmassakin tutkimuksessa (Werquin 2008; Chang ym. 2012), formaali oppiminen määrittyi opetussuunnitelmien ohjaamana ja kontrolloituna oppimisena, joka sijoittui opettajajohtoiseen luokkahuoneeseen. Laajempi, koko elämän kattava oppiminen taas ymmärrettiin kaikkialla ja koko ajan tapahtuvaksi oppimisprosessiksi. Näissä käsityksissä painottui aiemman tutkimuksen mukainen (Callanan ym. 2011) yksilöiden omien tavoitteiden ja mielenkiinnon mukainen oppiminen. Opettajaopiskelijoiden monipuolisimmat vastaukset kuvasivat valmiutta tietoiseen toimintakulttuurin kyseenalaistamiseen. Informaalin ja koulutusjärjestelmän tuottaman formaalin oppimisen välistä dikotomiaa oltiin valmiita rikkomaan ja miettimään niiden keskinäistä suhdetta uudelleen. Tätä vaihtoehtoa on aiemmin korostettu tutkimuksessa (Grosemans ym. 2015).

Koska aineisto kerättiin opinnoissaan pitkälle edenneiltä opiskelijoilta, oppimisen käsitysten kirjo yllätti. Hämmennystä herättivät kapeat ja koulujärjestelmään rajautuneet käsitykset etenkin silloin, kun vastaus ei sisältänyt muita käsityksiä. Rohkaisevina kuvauksina puolestaan voidaan nostaa esiin moniulotteiset ja pohtivat vastaukset, joissa tuotettiin eksplisiittisiä käsityksiä työelämässä tarvittavasta oppimisen ja oppimisympäristöjen monimuotoisesta suhteesta. Teksteihin sisältyi yksityiskohtaisiakin kuvauksia aiemmin havaituista yhteistyön edellyttämistä taidoista (Vesterinen ym. 2017). Koko elämän laajuista oppimista koskevat käsitykset kertoivat vahvasta ja oma-aloitteisesta halusta liikkua perinteisiksi nimettyjen organisaatio- ja oppiainerajojen yli.

Opiskelijoiden kokemukset laajojen oppimisympäristöjen haasteellisuudesta voivat olla tulkittavissa mallioppimisena. Aiempien tutkimusten mukaan (Payne \& Zeichner 2017; Fredricks 2011; Callanan ym. 2011) sekä yliopistokoulutuksessa että opetustyössä tulisikin perehtyä oppijoiden omiin oppimisympäristöihin ja rohkaista niiden laajentamiseen, jotta koulutuksessa opittujen asioiden laajemmassa soveltamisessa tarvittavat merkityssuhteet rakentuisivat asianmukaisesti.

Tutkimuksen tulokset johdattivat pohtimaan opettajankoulutuksen vaikuttavuutta. Vaikka opiskelijoiden käsityksissä suhde oppimiseen monipuolisissa oppimisympäristöissä kuvautui myönteiseksi, käsitykset olivat kaukana toisistaan. Tutkimuksessamme havaittu oppimista ja oppimisympäristöjä koskevien käsitysten tason vaihtelu - tehtävän luonne huomioiden - osoittaa, että käsitysten tuottaminen perustuu parhaimmillaan kriittiseen ja monipuoliseen reflektointiin. Toisaalta aineistossa oli tekstejä, jotka kapealla tai olemattomalla, lähtökohtaisesti uskomusmaailmaan perustuvalla argumentaatiolla herättelivät pohtimaan opettajankoulutuksen vaikuttavuuden reunaehtoja hyvinkin kriittisesti. Tutkimuksen tulisikin suuntautua yhä enemmän siihen, millaisin käsityksin opiskelijat kentälle lähtevät ja miten heidän käyttöteoriansa koulutuksen aikana ja sen jälkeen rakentuu.

Vaikka opettajankoulutuksen loppuvaiheessa kerätystä aineistosta löytyikin vielä käsityksiä oppimisesta vain sulkeutuneen koulutusjärjestelmän sisällä, niin variaatiokirjon laajimpien kuvausten kategorioissa oppiminen nähdään olemassaolon tapana. Teksteissä tuotetaan vahvaa innovatiivista ja uutta oppimisympäristöajattelua kehittävää käsityskokonaisuutta.

Tutkimuksen aineisto koottiin opintotehtävänä. On ilmeistä, että opiskelijoiden sitoutuminen tehtävään vaihteli. Sitoutumisen vaihtelua emme tässä yhteydessä tulkitse. Analyysi perustui tuotettuihin käsityksiin. Yksittäinen vastaus fenomenografisessa tutkimuksessa voi tuottaa useita ja osin sisällöllisesti ristiriitaisia käsityksiä (Uljens 1989). Tutkimuksen aikana aineistoon on palattu yhä uudelleen, jotta variaatioiden rakenteen tuottaminen saataisiin mahdollisimman hyvin koko aineistoa kattavaksi (Sin 2010). 
Reflektointitehtävässä ei viitattu tietotekniikkaan erikseen. Teknologianäkökulman erillinen korostaminen tehtävänannossa olisi voinut painottaa tietotekniikan osuutta oppimisympäristökäsityksissä jopa tarpeettomasti. Kuitenkin tieto- ja viestintätekniikka liittyy keskeisesti opettajankoulutuksen oppimisympäristöihin (Sointu ym. 2016). Lisäksi kohderyhmän oppimistehtävänä oli sähköisen oppimateriaalin tuottaminen. Opiskelijoiden kokemukset tieto- ja viestintätekniikan hyödyntämisestä ja digitalisaation vaikutuksesta esimerkiksi kansalaisuuteen olivat kuitenkin vielä hyvin kapeita verrattuna esimerkiksi 21st Century Skills -ajatteluun (Ananiadou \& Claro 2009; Saltmarsh, Chapman, Campbell \& Drew 2015) Tieto- ja viestintätekniikan hyödyntämisessä painotettiin kulloisenkin opettajan henkilökohtaista motivaatiota ja valintamahdollisuutta.

Prosessi paljasti myös oman ajattelumme ristiriitaisuuksia. Avoin oppiminen ja avoimet oppimisympäristöt muodostavat kenttää, jonka kaikilla toimijoilla - tutkijat ja opettajankouluttajat mukaan lukien - on riski sotkeutua omien käsitystensä koulutusjärjestelmäkeskeisyyteen. Esimerkiksi perusopetuksen opetussuunnitelmassa (Opetushallitus 2014, 41) käytetty termi 'koulun ulkopuolinen oppimisympäristö' ohjaa toimimaan aktiivisesti koulun ulkopuolella ja samalla alleviivaa koulun ja sen ympäröivän yhteisön erillisyyttä. Tätä terminologiaa käytimme myös tehtävänannossa: "Millaisena näet oppimisen koulun ulkopuolisissa ympäristöissä?" Vaikka tehtävänanto kriittisesti katsottuna ohjaa dikotomisen formaalin ja informaalin oppimisympäristöajattelun suuntaan, niin tuotetut käsitykset laajimmillaan kykenivät sen ylittämään.

Pedagogiset opinnot tähtäävät tämän tutkimuksen kontekstissa opettajan pätevyyteen ja ammatissa tarvittavien osaamisalueiden kehittämiseen. Opettajien pätevyys määritellään lainsäädännössä. Voidaankin kysyä, rakennammeko opettajankoulutuksen ja opettajuuden toimintakulttuuria edelleen liiankin luokkahuone- ja koulutusjärjestelmäkeskeiseksi, jolloin koulutusjärjestelmän ulkopuolella tapahtuvan oppimisen ja oppimiseen liittyvien ympäristöjen eksplisiittinen käsittely jää kapeaksi. Työelämätaitojen näkökulmasta katsottuna opiskelijoilla tulee valmistuessaan olla näkymä omakohtaiseen ja jatkuvaan oppimiseen. Toisaalta on syytä kiinnittää huomioita oppimiseen ja sen reunaehtoihin. Opettajankoulutuksessa tulee pohtia miksi, miten ja kenen etuja painottaen oppimisen jatkumoita ohjataan (esim. Biesta 2006).

Opettajaopiskelijoille tulee jo akateemisten opintojen aikana rakentua valmiutta osallistua kaikenikäisiä oppijoita koskevaan yhteiskuntatietoiseen keskusteluun, jossa pohditaan oppimisoikeuden ja -velvollisuuden rajoja ja sisältöjä. Oppimisympäristöt ja niiden nopea muuttuminen vaativat uutta näkökulmaa oppimisen ja opetuksen ja niihin sisältyvän kompleksisuuden tutkimukseen.

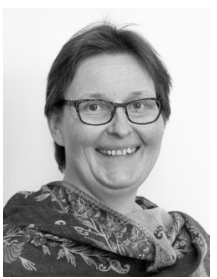

TEIJA KOSKELA

$K T$, yliopistotutkija kasvatustieteiden tiedekunta Turun yliopisto

(iD https://orcid.org/0000-00017331-5212

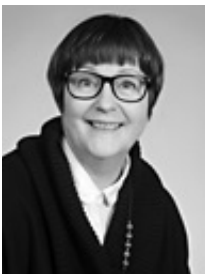

PÄIVI ROSENIUS

KM, yliopisto-opettaja filosofinen tiedekunta Itä-Suomen yliopisto

(iD https://orcid.org/0000-00029920-4657

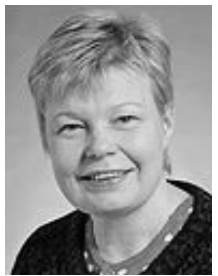

SIRPA KÄRKKÄINEN

$\mathrm{FT}$, dosentti, vanhempi yliopistonlehtori filosofinen tiedekunta Itä-Suomen yliopisto

(D) https://orcid.org/0000-00020515-0775 
Alston, G. D. \& Ellis-Hervey, N. (2015). Exploring the nonformal adult educator in twenty-first century contexts using qualitative video data analysis techniques. Learning, Media and Technology 40(4), 502-513. DOI: https://doi.org/10.1080/17439884.201 4.968168

Ammattikorkeakoululaki 932/2014. https://www.finlex.fi/fi/ laki/ajantasa/2014/20140932 (7.1.2019).

Ananiadou, K. \& Claro, M. (2009). 21st Century Skills and Competences for New Millennium Learners in OECD Countries. OECD Education Working Papers 41. Paris: OECD Publishing.

Biesta, G. (2006). What's the point of lifelong learning if lifelong learning has no point? On the democratic deficit of policies for lifelong learning. European Educational Research Journal 5(3-4), 169-180. DOI: https://doi.org/10.2304/eerj.2006.5.3.169.

Bourke, R., O'Neill, J. \& Loveridge, J. (2018). What starts to happen to assessment when teachers learn about their children's informal learning? Australian Education Research 45, 33-50. DOI: https://doi.org/10.1007/ s13384-018-0259-x.

Callanan, M., Cervantes, C. \& Loomis, M. (2011). Informal Learning. Cognitive Science 2(6), 646-655. DOI: https:// doi.org/10.1002/wcs.143.

Chang C.-Y., Hagman J.-G., Chien Y.-T. \& Cho, C.-W. (2012). Leveraging educational pathway to bridge in-school and out-of-school science learning: A comparison of different instructional designs. Journal of Baltic Science Education 11(3), 275-284.

Eikeland, O. (2012). Symbiotic Learning Systems: Reorganizing and Integrating Learning Efforts and Responsibilities between Higher Educational Institutions (HEls) and Work Place. Journal of the Knowledge Economy 4(1), 98-118. DOI: https://doi.org/10.1007/ s13132-012-0123-6.

Fredricks, J. (2011). Engagement in School and Outof-School Contexts: A Multidimensional View of Engagement. Theory into Practice 50, 327-335. DOI: https://doi.org/10.1080/00405841.2011.607401.

Grosemans, I., Boon, A., Verclairen, C., Dochy, F. \& Kyndt, E. (2015). Informal learning of primary school teachers: Considering the role of teaching experience and school culture. Teaching and Teacher education 47, 151-161. DOI:https://doi.org/10.1016/j.tate.2014.12.011.

Haapakorpi, A. (2009). Sulkeuman ja neuvottelun ehdoilla - asiantuntija-aseman rakentuminen työelämässä. Sosiologian laitos. Helsinki: Helsingin yliopisto. https:// helda.helsinki.fi/bitstream/handle/10138/23469/ sulkeuma.pdf? sequence=2\&isAllowed=y (7.1.2020).

Hakkarainen, K. (2017). Kollektiivinen luovuus, yhteisöllinen oppiminen ja itsensä ylittäminen. Aikuiskasvatus 37(1), 47-56. DOI: https://doi.org/10.33336/aik.88397.
Hakkarainen, K., Lallimo, J. \& Toikka, S. (2012). Kollektiivinen asiantuntijuus ja jaetut tietokäytännöt Aikuiskasvatus 34(4), 247-256. DOI: https://doi.org/ 10.33336/aik.94003.

Herron, R. \& Mendiwelso-Bendek, Z. (2018). Supporting selforganised community research through informal learning. European Journal of Operational Research 268, 825-835. DOI: https://doi.org/10.1016/j.ejor.2017.08.009.

Holma, K. (2013). Kriittinen ajattelu kasvatuspäämääränä. niin\&näin - filosofinen aikakauslehti 78(3), 97-103.

Hung, P.-H., Hwang, G.-J., Lee, Y.-H., Wu, T.-H., Vogel, B., Milrad, M., \& Johansson, E. (2014). A Problembased Ubiquitous Learning Approach to Improving the Questioning Abilities of Elementary School Students. Educational Technology \& Society 4, 316-334.

Karila, K., Turtiainen, H. \& Ukkonen-Mikkola, T. (2015). Yhteistä toimintaa koulutuksen ja työelämän rajavyöhykkeellä. Yliopistopedagogiikka 22(1), 20-22.

Kerosuo, H. (2014). Kollektiivinen muutostoimijuus - esimerkkinä solmutyöskentely rakennusalan kehittämishankkeessa. Aikuiskasvatus 34(3), 178-191. DOI: https://doi.org/10.33336/aik.94098.

Kompen, R. T., Edirisingha, P., Canaleta, X., Alsina, M. \& Monguet, J. P. (2019). Personal learning Environments based on Web 2.0 services in higher education. Telematics and Informatics 38, 194-206. DOI: https:// doi.org/10.1016/j.tele.2018.10.003.

Kumpulainen, K. \& Mikkola, A. (2015). Oppiminen ja koulutus digitaalisella aikakaudella. Teoksessa M. Kuuskorpi (toim.) Digitaalinen oppiminen ja oppimisympäristöt. Julkaisu 2015:1. Tampere: Juvenes Print, 9-45.

Laki ammatillisesta koulutuksesta 531/2017. https://www. finlex.fi/fi/laki/ajantasa/2017/20170531. (7.1.2019).

Laru, J. (2014). "Mä haluun näyttää sulle mun skrätsin". Kasvatus 45(5), 467-468.

Leeferink, H., Koopman, M., Beijaard, D. \& Schellings, G.L.M. (2019). Overarching professional identity themes in student workplace learning. Teachers and Teaching 25(1), 69-89. DOl:https://doi.org/10.1080/13540602. 2018.1527762.

List, A. \& Brante, E., \& Klee, H. (2020). A framework of pre-service teachers' conceptions about digital literacy: Comparing the United States and Sweden. Computers \& Education, 148, 1-68. DOI: https://doi.org/10.1016/j. compedu.2019.103788.

Manninen, J., Burman, A., Koivunen, A., Kuittinen, E., Luukannel S., Passi, S. \& Särkkä, H. (2007). Oppimista tukevat ympäristöt. Johdatus oppimisympäristöajatteluun. Helsinki: Opetushallitus.

Marton, F. \& Booth, S. (1997). Learning and Awareness. Mahwah, New Jersey: Lawrence Erlbaum.

McGivern, P. (2014). Emergent Expertise? Educational Philosophy and Theory 46(6), 692-708. DOI: 
https://doi.org/10.1080/00131857.2013.779217.

Menary, R. \& Kirchhoff, M. (2014). Cognitive

Transformations and Extended Expertise. Educational Philosophy and Theory 46(6), 610-623. DOI: https://doi. org/10.1080/00131857.2013.779209.

Mertala, P. (2019). (Vasta)kertomuksia koulutuksen digitalisaatiosta. Kasvatus \& Aika 13(3), 26-45. DOl: https://doi.org /10.33350/ka.76593.

Opetushallitus (2014). Perusopetuksen opetussuunnitelman perusteet 2014. Määräykset ja ohjeet 2014:96. Helsinki: Opetushallitus.

Opetus- ja kulttuuriministeriö (2016). Opettajankoulutuksen kehittämisen suuntaviivoja. Opettajankoulutusfoorumin ideoita ja ehdotuksia. Opetus- ja kulttuuriministeriön julkaisuja 2016:34.

Parviainen, J. (2015). Teknologisoituva koulu oppimisen elämyspuistona: valtion opetusteknologiastrategian jalkauttaminen kouluihin 2010-luvulla. Kulttuurintutkimus 32(2), 3-14.

Payne, K. \& Zeichner, K. (2017). Multiple voices and participants in teacher education. Teoksessa D. J. Clandinin \& J. Husu (toim.) The Sage Handbook of Research on Teacher Education. Los Angeles, CA: Sage. 1101-1116.

Penttinen, L., Skaniakos, T., Lairio, M. \& Ukkonen, J. (2011). Korkeakouluopiskelun pedagoginen työelämähorisontti. Miten työelämäorientaatiota voidaan tukea koulutuksen aikana? Aikuiskasvatus 31(2), 99-110. DOI: https://doi. org/10.33336/aik.93921.

Plessis, du, A. E. (2015). Effective education: Conceptualising the meaning of out-of-field teaching practices for teachers, teacher quality and school leaders. International Journal of Educational Research 72, 89102. DOI: https://doi.org/10.1016/j.ijer.2015.05.005.

Rajaniemi, J., Häkli, J., Rauhala, K. \& Sumkin, H. (2018). Urbanisoituva yliopistokampus informaalin oppimisen mahdollistajana. Aikuiskasvatus 38(1), 18-29.

Rehm, M. \& Notten, A. (2016). Twitter as an informal learning space for teachers!? The role of social capital in Twitter conversations among teachers. Teaching and Teacher education 60, 215-223. DOI: https://doi. org/10.1016/j.tate.2016.08.015.

Saari, A. (2016). Elinikäinen oppiminen ja yksilöivä valta. Aikuiskasvatus 1, 4-13.

Salmi, H., Kaasinen, A. \& Kallunki, V. (2012). Towards an Open Learning Environment via Augmented Reality (AR): visualising the invisible in science centres and schools for teacher education. Procedia - Social and Behavioral Sciences 45, 284 - 295. DOI: https://doi. org/10.1016/j.sbspro.2012.06.565.

Saltmarsh, S., Chapman, A., Campbell, M. \& Drew, C. (2015). Putting "structure within the space": spatially un/responsive pedagogic practices in open-plan learning environments. Educational Review 67(3), 315-327. DOI:https://doi.org/10.1080/00131911.2014.924482.
Sin, S. (2010). Considerations of quality in phenomenographic research. International Journal of Qualitative Methods 9(4), 305-319. DOI: https://doi. org/10.1177/160940691000900401.

Sointu, E., Valtonen, T., Kukkonen, J., Kärkkäinen, S., Koskela, T., Pöntinen, S., Rosenius, P. \& Mäkitalo-Siegl, K. (2016). Quasi-Experimental Study for Enhancing PreService Teachers' TPACK. Teoksessa G. Chamblee \& L. Langub (toim.) Proceedings of Society for Information Technology \& Teacher Education International (SITE) Conference 2016. Association for the Advancement of Computing in Education (AACE). 3067-3074.

Toom, A., Pietarinen, J., Soini, T. \& Pyhältö, K. (2017). How does the learning environment in teacher education cultivate first year student teachers' sense of professional agency in the professional community. Teaching and Teacher Education 63, 126-136. DOI: https://doi.org/10.1016/j.tate.2016.12.013.

Uljens, M. (1989). Fenomenografi-forskning om uppfattningar. Lund: Studentlitteratur.

Valtioneuvosto (2012). Valtioneuvoston asetus perusopetuslaissa tarkoitetun opetuksen valtakunnallisista tavoitteista ja perusopetuksen tuntijaosta 422/2012.

Vesterinen, O., Kangas, M., Krokfors, L., Kopisto, K. \& Salo, L. (2017). Inter-professional pedagogical collaboration between teachers and their out-of-school partners. Educational Studies 43(2), 231-242. DOI: https://doi.org /10.1080/03055698.2016.1277131.

Vihervaara, E. (toim.) (2009). Koe oppimisympäristönä. Länsi-Suomen läänin aikuislukioiden raportti koekäytänteiden kehittämisestä lukiossa II. LänsiSuomen läänin aikuislukiot.

Webster-Wright, A. W. (2009). Reframing professional development through understanding authentic professional learning. Review of Educational Research 79(2), 702-739.

Werquin, P. (2008). Recognition of non-formal and informal learning in OECD countries: A very good idea in jeopardy? Lifelong Learning in Europe 3, 142-149.

Westling Allodi, M. (2002). Children's experiences of school: narratives of Swedish children with and without learning difficulties. Scandinavian Journal of Educational Research 46(2), 181-205. DOI: https:// doi:10.1080/00313830220142191.

Winding, T. N. \& Andersen, J. H. (2015). Socioeconomic differences in school dropout among young adults: the role of social relations. BMC Public Health 15. DOI: https://doi: 10.1186/s12889-015-2391-0.

Virtanen A. \& Tynjälä, P. (2013). Kohti työelämätaitoja kehittävää yliopistopedagogiikkaa - opiskelijoiden näkökulma. Yliopistopedagogiikka 20(2), 2-10.

Åkerlind, G. (2005). Variation and commonality in phenomenographic research methods. Higher Education Research \& Development 24(4), 321-334. DOI: https:// doi.org/10.1080/07294360500284672. 